\title{
Do Dairy Cattle Need Protection against Weather in a Temperate Climate? A Review
}

\author{
Rony Geers ${ }^{1}$, Liesbeth Vermeulen ${ }^{1}$, Melissa Snoeks ${ }^{1} \&$ Liesbet Permentier $^{1}$ \\ ${ }^{1}$ Laboratory of Quality Care in Animal Production, KU Leuven, Belgium \\ Correspondence: Rony Geers, Laboratory of Quality Care in Animal Production, KU Leuven, Bijzondere weg 12, \\ B-3360 Lovenjoel, Belgium. Tel: 32(0)-1646-8133. E-mail: rony.geers@biw.kuleuven.be
}

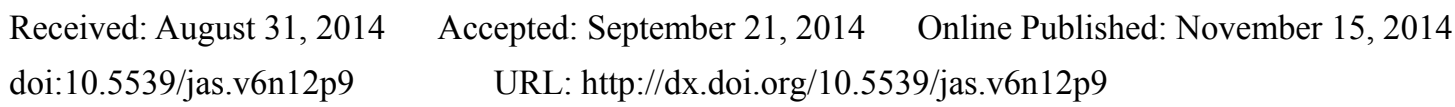

\begin{abstract}
Information on effects of weather conditions on milk production of dairy cows is rather scarce. Legislation exists in some countries saying when and how protection should be available for cows on pasture. Producers refer to the extra costs, and are not always convinced of the return of investment. Therefore, (re)production variables of high producing dairy cows were reviewed in relation to weather conditions in a mild climate. The objective was to understand mechanisms cows are using for acclimatization, which might affect (re)production, and to propose managing tools. An overall critical dry air temperature seems to be about $16{ }^{\circ} \mathrm{C}$, with cumulative interactions from relative humidity, wind speed, radiation and rain fall. The explanation is related to the cow's thermoregulatory physiology associated with her heat and energy balance, as a primary need. Modulating factors, such as breed, individual capacity, feed composition and farm management have to be taken into account.

The effects have to be considered as important at herd level, especially in a system with year round calving, since production might be below peak production up to six months of the year. Planning of day of calving should avoid peak production during summer, since mild heat stress might counteract the expression of genetic progress for (re)production. However, since the most important factor seems to be the level of dry air temperature, the effects will be independent of protection or not. Hence, there will be no direct return of investment moneywise, but indirectly as appreciation from society for animal welfare.
\end{abstract}

Keywords: dairy cow, production, reproduction, mild climate, legislation

\section{Introduction}

Effects of variables related to weather conditions on production and reproduction characteristics of cattle are well-known. Also the need for sheltering has been studied (Vandenheede et al., 1992; Tucker et al., 2007; Schütz, Cox, \& Matthews, 2008). Even the impact of a combined effect of weather conditions has been established in order to take preventive measures, such as shelter and diet, in relation to weather forecast (Legrand, von Keyserlingk, \& Weary, 2008). Attention has been focused on the combined effect of dry air temperature and relative humidity on milk production, allowing the definition of combinations being considered as safe, alert and danger, not only for production, but also for protecting animal welfare (Thorn, 1959; Yousef, 1985; Johnson, 1987; Bohmanova, Misztal, \& Cole, 2007; Mader, Johnson, \& Gaughan, 2010; Tao \& Dahl, 2013). Solar radiation was found to increase the risk of heat stress, explaining $51.4 \%$ of the observed variability compared to $32.2 \%$ for dry bulb temperature, $8.9 \%$ for dew point temperature and $5.7 \%$ for wind speed (Eigenberg, Brown-Brandl, Nienaber, \& Hahn, 2005). Wind speed was able to reduce the risk of heat stress, but might increase the risk of cold stress (Curtis, 1983; Yousef, 1985; Collier, Zimbelman, R. P. Rhoads, M. L. Rhoads, \& Baumgard, 2006). These effects are considered as main stream, but modulated by animal related factors, such as breed, age, adaptation capacity, behavior, ... (e.g. Fisher, Roberts, Bluette, Verkerk, \& Matthews, 2008, Thompson, Fadel, \& Sainz, 2011; Johnson, Scharf, Weaber, Eichen, \& Spiers, 2012). In fact, interactions explained relatively more the observed variation in test data than main factors such as dry air temperature or dew point temperature (Brown-Brandl, Jones, \& Woldt, 2005). However, also postponed physiological effects from a few days up to two to six weeks after the climatological event have to be considered (Jordan, 2003; Morton, Tranter, Mayer, \& Jonsson, 2007; D. L. Smith, T. Smith, Rude, \& Ward, 2013). This seems to be well documented for reproduction characteristics such as number of inseminations per conception, conception rate and days open, although others found the largest effect from the weather conditions at or close to the day of 
insemination, e.g. a drop up to $80 \%$ in conception rate (Ingraham, Gillette, \& Wagner, 1971; Cavestany, EL-Wishy, \& Foote, 1985; Ravagnolo \& Misztal, 2002; Mellada et al., 2010).

Most of the published results are related to extreme weather conditions. The legislation in some countries (e.g. Austria, Denmark (during winter), France, Norway, Portugal, Sweden (during winter), Switzerland) is based on this scientific evidence, saying that dairy cows must have the choice to be protected against adverse weather conditions. In other countries (e.g. Belgium, Denmark (during summer), Sweden (during summer)) the formulation of legislation is only referring to the general principle of protection of animal welfare as stated in the legislation of the European Union. Hence, it is interesting to know what effects may be when dairy cattle is kept in a mild temperate climate. One can suppose that high yielding dairy cattle are more prone to an increase of environmental temperature, whereby reduction of milk production, i.e. reducing heat production, can be an adaptation mechanism to cope with mild increasing environmental temperature. In fact, even for feedlot cattle an alert value for thermal humidity index (THI) of 68 is already reported, i.e. the combination of $23.6{ }^{\circ} \mathrm{C}$ dry air temperature with 77.5\% relative humidity (RH) (Brown-Brandl, Eigenberg, Nienaber, \& Hahn, 2005). In the past, when $305 \mathrm{~d}$ milk production per cow was lower, a THI of 72 was considered as being critical. Effects of THI in temperate conditions on Holstein dairy cows are already reported in relation to production on the day of testing (Brügemann, Gernand, von Borstel, \& König, 2011; Hammami, Bormann, M'hamdi, Montaldo, \& Gengler, 2013), but not in relation to $305 \mathrm{~d}$ production and reproduction records, nor taking into account weather conditions on the day of calving or insemination.

It is clear that effects of extreme weather conditions are very well documented for dairy cows, while effects of mild conditions need more attention in view of genetic selection for steady higher production versus constraints from global warming. Therefore, production and reproduction characteristics of high yielding dairy cattle were studied in relation to weather conditions in a temperate climate in order to fill that knowledge gap. Attention is also paid to the return of investment, because producers do not see benefits from protection when dairy cows are on pasture, as being required by animal rights organizations claiming to speak for the animals and societal concerns.

\section{Method}

The scientific literature was reviewed. First, relevant papers were collected based on a search in electronic publications via the LIMO system developed and licensed by KU Leuven. The used key words were: cattle, dairy cow, heat stress, milk, production, reproduction, temperature, thermoregulation, weather variables. Also relevant textbooks were consulted, so that in total 79 full-text references were used for further processing. In a second step methodology and results of similar studies were critically compared. Finally, studies were merged according to the topics reported in this review, including a qualitative and quantitative synthesis to formulate conclusions (Moher et al., 2009).

Regression equations were calculated with Excel software (Microsoft Office, 2007). The data used were mean values calculated on resp. 727, 25505, 11, 17 and 200 records (Hansen \& Aréchiga, 1997; Morton et al., 2007; Nabenishi et al., 2011; Tao \& Dahl, 2013; Zimbelman et al., 2007). One can assume normality of distribution of the original population, based on the central limit theorem stating that the distribution of the sum (or average) of a large number of independent, identically distributed variables will be approximately normal, regardless of the underlying distribution (Stigler, 1986).

\section{Definition of a Mild Climate}

These climates have an average temperature above $10{ }^{\circ} \mathrm{C}$ in their warmest months (April to September in northern hemisphere), and a coldest month average between -3 and $18{ }^{\circ} \mathrm{C}$ (Peel et al., 2007).

An example is the weather conditions in Belgium and The Netherlands. The descriptive statistics are reported in Table 1 as monthly values averaged over 12 years. 
Table 1. Mean, standard deviation, minimum and maximum for dry air temperature $\left({ }^{\circ} \mathrm{C}\right)$, relative humidity $(\%)$, wind velocity $(\mathrm{m} / \mathrm{s})$, radiation $\left(\mathrm{kJ} / \mathrm{cm}^{2}\right)$, rain duration (minutes) and rain intensity $(\mathrm{mm})$ for each month in the period $2000-2011$

\begin{tabular}{|c|c|c|c|c|c|}
\hline Month & Variable & Mean & Standard deviation & Minimum & Maximum \\
\hline & Dry air temperature: ${ }^{\circ} \mathrm{C}$ & & & & \\
\hline January & & 3.07 & 4.22 & -13.0 & 13.5 \\
\hline February & & 3.71 & 3.56 & -5.90 & 15.0 \\
\hline March & & 5.80 & 3.54 & -9.10 & 15.9 \\
\hline April & & 10.2 & 3.48 & 0.10 & 21.5 \\
\hline May & & 13.0 & 3.06 & 5.20 & 24.6 \\
\hline June & & 16.0 & 2.88 & 8.10 & 27.2 \\
\hline July & & 17.9 & 2.87 & 11.9 & 28.3 \\
\hline August & & 17.4 & 2.44 & 11.0 & 28.3 \\
\hline September & & 14.8 & 2.62 & 7.40 & 22.5 \\
\hline October & & 10.9 & 3.33 & -1.30 & 20.1 \\
\hline November & & 7.36 & 3.28 & -4.20 & 16.4 \\
\hline \multirow[t]{2}{*}{ December } & & 3.24 & 4.09 & -11.3 & 13.6 \\
\hline & Relative humidity: \% & & & & \\
\hline January & & 89.1 & 6.49 & 55.0 & 100 \\
\hline February & & 87.6 & 8.12 & 51.0 & 100 \\
\hline March & & 82.8 & 8.47 & 41.0 & 99.0 \\
\hline April & & 75.6 & 10.4 & 37.0 & 99.0 \\
\hline May & & 75.2 & 10.6 & 37.0 & 98.0 \\
\hline June & & 77.0 & 8.06 & 47.0 & 97.0 \\
\hline July & & 78.8 & 8.57 & 41.0 & 97.0 \\
\hline August & & 81.8 & 7.08 & 48.0 & 99.0 \\
\hline September & & 83.6 & 6.30 & 57.0 & 99.0 \\
\hline October & & 86.7 & 6.08 & 58.0 & 99.0 \\
\hline November & & 90.4 & 5.72 & 59.0 & 100 \\
\hline \multirow[t]{2}{*}{ December } & & 90.9 & 6.46 & 60.0 & 100 \\
\hline & Wind velocity: $\mathrm{m} / \mathrm{s}$ & & & & \\
\hline January & & 4.74 & 2.58 & 0.10 & 15.3 \\
\hline February & & 4.28 & 2.44 & 0.10 & 15.2 \\
\hline March & & 4.23 & 2.27 & 0 & 15.7 \\
\hline April & & 3.61 & 1.97 & 0.20 & 13.6 \\
\hline May & & 3.81 & 1.94 & 0.10 & 12.4 \\
\hline June & & 3.37 & 1.89 & 0.10 & 13.9 \\
\hline July & & 3.30 & 1.94 & 0.10 & 13.9 \\
\hline August & & 3.17 & 1.77 & 0.10 & 12.9 \\
\hline September & & 3.34 & 2.07 & 0 & 14.5 \\
\hline October & & 3.86 & 2.02 & 0 & 14.1 \\
\hline November & & 4.23 & 2.19 & 0.10 & 16.9 \\
\hline
\end{tabular}




\begin{tabular}{|c|c|c|c|c|c|}
\hline December & & 4.18 & 2.34 & 0 & 15.1 \\
\hline & Radiation: $\mathrm{kJ} / \mathrm{cm}^{2}$ & & & & \\
\hline January & & 653 & 427 & 44 & 2120 \\
\hline February & & 1180 & 743 & 111 & 3786 \\
\hline March & & 2457 & 1218 & 228 & 5303 \\
\hline April & & 4315 & 1414 & 667 & 7222 \\
\hline May & & 5063 & 1897 & 578 & 9499 \\
\hline June & & 5472 & 1830 & 728 & 8994 \\
\hline July & & 5071 & 1726 & 731 & 8420 \\
\hline August & & 4098 & 1465 & 475 & 7328 \\
\hline September & & 3046 & 1195 & 256 & 5725 \\
\hline October & & 1762 & 822 & 164 & 3828 \\
\hline November & & 747 & 405 & 19.5 & 2096 \\
\hline December & & 471 & 286 & 47.2 & 1525 \\
\hline & Rain: number of minutes & & & & \\
\hline January & & 150 & 216 & 0 & 1284 \\
\hline February & & 144 & 202 & 0 & 1344 \\
\hline March & & 104 & 179 & 0 & 1440 \\
\hline April & & 59.5 & 120 & 0 & 894 \\
\hline May & & 85.7 & 154 & 0 & 1194 \\
\hline June & & 66.6 & 120 & 0 & 912 \\
\hline July & & 98.9 & 166 & 0 & 1320 \\
\hline August & & 90.3 & 147 & 0 & 1260 \\
\hline September & & 87.5 & 163 & 0 & 1266 \\
\hline October & & 97.5 & 162 & 0 & 1302 \\
\hline November & & 148 & 197 & 0 & 1380 \\
\hline December & & 144 & 193 & 0 & 1254 \\
\hline & Rain intensity: mm & & & & \\
\hline January & & 2.35 & 4.28 & 0 & 37.8 \\
\hline February & & 2.03 & 3.61 & 0 & 31.8 \\
\hline March & & 1.58 & 3.20 & 0 & 35.7 \\
\hline April & & 1.13 & 2.77 & 0 & 26.2 \\
\hline May & & 1.87 & 4.13 & 0 & 43.8 \\
\hline June & & 1.98 & 4.49 & 0 & 75.9 \\
\hline July & & 3.23 & 5.84 & 0 & 60.0 \\
\hline August & & 3.24 & 7.23 & 0 & 142 \\
\hline September & & 2.12 & 4.51 & 0 & 53.6 \\
\hline October & & 2.15 & 4.19 & 0 & 62.1 \\
\hline November & & 2.45 & 4.43 & 0 & 87.9 \\
\hline December & & 2.33 & 3.86 & 0 & 40.3 \\
\hline
\end{tabular}




\section{Reproduction}

Textbooks report target values for number of inseminations 1.5, interval calving insemination 90 days and a between calving interval of 390 days. Hansen and Aréchiga (1997) found that embryos were most sensitive to a high body temperature one or two days after conception, but this effect could be extended to six days after insemination (Morton, Tranter, Mayer, \& Jonsson, 2007). Berman (2011) suggested breed differences, i.e. embryos from $B$. indicus cattle being more tolerant to high temperatures, but interactions from genetic differences attributed to sire effects independent of breed, and farm management should be taken into account. An increase of THI from 66 to 78 was associated with a decrease of conception rate from 47 to $27 \%$, while Nabenishi et al. (2011) found a decrease of only 12\%. The critical limit for THI in relation to a reduced conception rate in meat cattle was set at 73 , and for minimal daily dry air temperature at $17{ }^{\circ} \mathrm{C}$ (Amundson, Mader, Rasby, \& Hu, 2006). Roelofs, López-Gatiusc, Hunterd, van Eerdenburge and Hanzen (2010) found that a reduction of 1 day of interval calving to insemination decreased the between calving interval by 0.86 day.

A negative effect of mild heat on conception rate was explained as a short term effect by suppressing the signs of estrus, so that farmers failed in successful estrus detection (Swazdauskas, 1985; Casasús, Sanz, Villalba, Ferrer, \& Revilla, 2002). Of course, no estrus and no pregnancy mean also no increase in heat production. However, long term effects of heat stress on oocyte quality and early embryonic development are not excluded (Wolfenson, Roth, \& Meidan, 2000; Paula-Lopez et al., 2013). The question remains, whether it is the result of a single event within a sensitive period, or an effect of duration (several days or a series of days) in combination with a suboptimal environment. Hammami et al. (2013) reported a mean value of 80 days a year between 2000 and 2011 with a THI being considered as too high, in the province Luxemburg, South-West of Belgium. Avendano-Reyes et al. (2006) reported an increase of services per conception up to $34 \%$ in case cows were not cooled during the dry period at dry air temperatures up to $50{ }^{\circ} \mathrm{C}$. Such an increase was also the case for the number of open days.

Table 2. Summary of results on variability of conception rate $(\%)$ and dry air temperature $\left({ }^{\circ} \mathrm{C}\right)$, THI and vaginal temperature $\left({ }^{\circ} \mathrm{C}\right) . \Delta$ means percentage increase or decrease

\begin{tabular}{|c|c|c|c|c|}
\hline Dry air temperature ${ }^{\circ} \mathrm{C}$ & THI & Vaginal temperature ${ }^{\circ} \mathrm{C}$ & Conception rate $\%$ & Authors \\
\hline Cooled & & $39.2(0.14)$ & $55(3)$ & \\
\hline \multirow[t]{2}{*}{ Not cooled } & & $39.4(0.14)$ & $41(3)$ & Avendo-Reyes et al. (2006) \\
\hline & & & $\Delta=-25 \%$ & \\
\hline 25 & & & 30 & \\
\hline 35 & & & 10 & Hansen \& Aréchiga (1997) \\
\hline \multirow[t]{4}{*}{$\Delta=+40 \%$} & & & $\Delta=-67 \%$ & \\
\hline & 66 & & 46 & \\
\hline & 78 & & 25 & Morton et al. (2007) \\
\hline & $\Delta=+18 \%$ & & $\Delta=-46 \%$ & \\
\hline 19.7 & $<70$ & $38.5(0.1)$ & 38 & \\
\hline 30.7 & $>70$ & $40.5(0.2)$ & 25 & Nabenishi et al. (2011) \\
\hline$\Delta=+55.8 \%$ & & $\Delta=+5.20 \%$ & $\Delta=-34 \%$ & \\
\hline
\end{tabular}




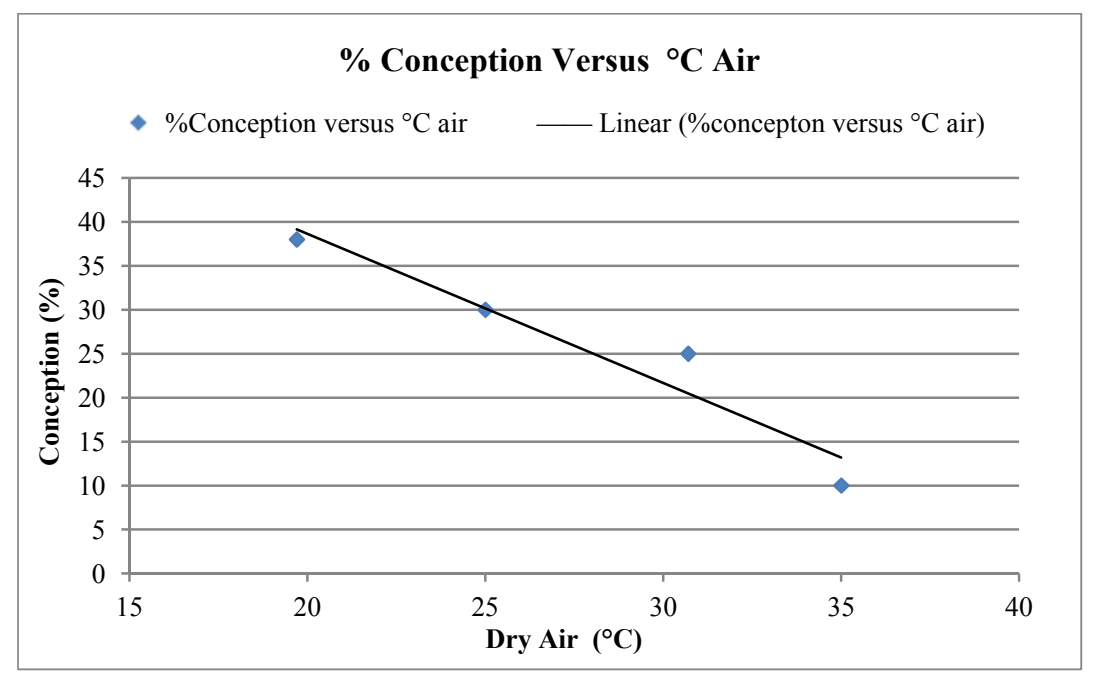

Figure 1. Conception rate $(\%)$ versus dry air temperature $\left({ }^{\circ} \mathrm{C}\right)$, based on the results reported by Hansen and Aréchiga (1997), Morton et al. (2007) and Nabenishi et al. (2011), with \% conception $=72.6-1.70{ }^{\circ} \mathrm{C}(\mathrm{r}=$ $-0.9610 ; \mathrm{P}<0.05)$

Table 2 shows that conception rate might be reduced up to $67 \%$ when dry air temperature increased with $40 \%$, but depending on the level of dry air temperature and interaction with $\mathrm{RH}$. This association is reported in the four refereed different studies, so that the mean effect may be considered as independent from breed, housing and management between these studies.

The explanation is mainly formulated in relation to the physiology of the cow. Wolfenson, Roth, and Meidan (2000) found lower levels of estrogen, progesterone and LH when cows showed signs of heat stress around time of insemination, impairing the development of the embryo, increasing embryonic mortality. Paula-Lopes, Lima, Satrapa, and Barros (2013) stated that heat stress during maturation of the oocyte and during first cleaving division, could induce cellular damage in the cytoplasmatic and nuclear components. The increase in the number of inseminations, up to $100 \%$, was explained by a drop in estrus detection rate (Hansen \& Arechija, 1997), and probably related to a reduced duration and intensity of estrus (Jordan, 2003).

\section{Milk Production}

The higher critical temperature for a reduction of milk production, i.e. $3 \%$, was set at $29{ }^{\circ} \mathrm{C}$, in combination with a RH of $40 \%$ and $30 \%$ in combination with $90 \%$ RH (West, 2003). Protection by shade increased milk production with $10 \%$. The proposed shaded area per cow is $4.2-5.6 \mathrm{~m}^{2}$, while Schütz, Rogers, Poulouin, Cox, and Tucker (2010) recommended $9.6 \mathrm{~m}^{2}$. However, certain rules in relation to geometrical parameters have to be applied (Berman \& Horovitz, 2012). Feeding during the night and paddocks were preferred in stead of providing shade by trees, reducing pasture growth (Ainsworth, Moe \& Skarpe, 2012). Dry air temperature two days before milking had the largest impact, i.e. a $10 \%$ drop in milk quantity and $20 \%$ lower casein content (Nardone, Ronchi, Lacetera, \& Bernabucci, 2006). A lag time of two days was also reported by Bertocchi et al. (2014), but with respect to the effect of THI on milk composition. Butler, Stergiadis, Seal, Eyre, and Leifert (2011) found no effect on protein content, but a drop of fat content with $6 \%$. Seasonal effects on milk production were also reported, with $7 \%$ higher milk production when calving in December compared to June (Barash, Silanikove, Shamay, \& Ezra, 2001).

The fact that the average kg milk of the test samples is higher in April than in October, being months with the same daily mean dry air temperature, might also be explained by an increasing photoperiod in the months before April (Bertocchi et al., 2014). However, Bertocchi et al. (2014) did not report on data related to kg milk, but assumed that a drop in \%fat or \%protein might not only be explained by an increase of THI, but also by a dilution effect caused by an increase of kg milk associated with a longer photoperiod in spring, since values of THI can be the same in spring and autumn. Unfortunately, THI and photoperiod increase or decrease together, and cannot be separated from the season for the data being investigated. The negative effect of high air temperatures on milk production overruling the positive effect of increasing photoperiod was reported by Barash et al. (2001). 


\section{Thermoregulation and Negative Energy Balance}

These impacts are explained by the fact that thermoregulatory mechanisms, including reduced feed intake, maintain thermal balance at the expense of milk production and reproductive efficiency (Shearer \& Beede, 1990; Kadzere, Murphy, Silanikove, \& Maltz, 2002). Indeed, an increase of respiratory frequency, i.e. energy consuming muscular activity, was observed when dry air temperature exceeded $20^{\circ} \mathrm{C}$ (Nienaber \& Hahn, 2007). In case an increase of rectal temperature could not be avoided, i.e. in non diseased cows (Wenz, Moore, \& Kasimanickam, 2011), milk production decreased (Umphrey, Moss, Wilcox, \& Van Horn, 2001). The first sign of loss of thermal comfort is looking for shelter (Tucker, Rogers, \& Schütz, 2008). Time spent on pasture during daytime dropped from $60 \%$ to $40 \%$, being significant despite a range of $10 \%$ around the mean, with an increase of THI from 54 to 68, when provided free access to pasture and free stall housing (Falk, Weary, Winckler, \& von Keyserlingk, 2012). Cows were found to be 5 times more in shadow when dry air temperature was higher than $25{ }^{\circ} \mathrm{C}$ (Schütz et al., 2008, 2010), resulting in a lower respiration frequency when being in shade (Eigenberg, Brown-Brandl, Nienaber, \& Hahn, 2005; Schütz et al., 2010). A time lag of several hours was observed before feedlot cattle showed an increase of deep body temperature and/or respiration rate, which was shorter in case of weather conditions indicating alert, danger or emergency for heat stress (Brown-Brandl, Eigenberg, Nienaber, \& Hahn, 2005; Sharf et al., 2011). The importance of water intake to maintain deep body temperature, but also mineral metabolism to compensate for sweating, is paramount (Silanikove, 2000).

Zimbelman et al. (2009) re-evaluated the threshold of THI associated with a reduction of milk production. They proposed a value of 68 as threshold for current high producing cows in stead of $72\left(25^{\circ} \mathrm{C}\right.$ in combination with $50 \% \mathrm{RH}$ ), applied in the past to predict risk for heat stress. Bertocchi et al. (2014) proposed a critical value for THI between 50.2 and 72.8, depending on the parameter for milk composition investigated, i.e. somatic cell count, total bacterial count, percentage fat or protein.

A lower milk production during the subsequent lactation as a result of heat stress during the preceding dry period is explained either by a direct effect on mammary tissue growth (Adin et al., 2009) and indirectly by a shorter growing period of the mammary gland due to a shortened pregnancy period (Tao \& Dahl, 2013). A decrease in fertility is explained as an effect of a negative energy balance on the quality of oocytes and embryos, as indicated by an increased calving - conception interval (De Rensis \& Scaramuzzi, 2003). A negative energy balance is mainly related to the fact that feed intake cannot match the requirements for growth and/or pregnancy and/or milk production. Feed intake can be reduced to cope with high temperature, whether or not in combination with high humidity (Sharf et al., 2012).

It is generally accepted that homoeothermy is maintained by adapting simultaneously heat production and heat loss (conduction, convection, radiation, evaporation). In case heat loss is reduced because of a too small difference between body temperature and dry air temperature, and/or a reduced gradient in vapor pressure, less heat will be produced by e.g. reducing feed intake, resulting in a decreased milk production. This central mechanism is illustrated in Figure 2, showing the negative relationship between variability of deep body temperature and variability of milk production. An increase of deep body temperature is explained by heat accumulation, i.e. heat production higher than heat loss and/or heat transfer from the environment to the body. The reduction of milk production might be explained by the fact that the maximal capacity of heat loss is operational, and heat production needs to be lowered aiming to keep deep body temperature within the set range as a primary need. Variability with respect to the regression line indicates that when the increase of deep body temperature is small, variability within reduction of milk production is higher than at higher rectal temperatures, despite differences between the sources of data. Probably, when the increase of rectal temperature can be considered as still small, there might be an overlap between mechanisms of physical thermoregulation and reduction of heat production, while at higher rectal temperature the potential for heat loss is at its maximum, adding less variability. As long as the reference temperature set in the hypothalamus is still changing aiming for acclimatization (Bligh, 1966), feed intake and milk production have to be reduced, decreasing heat production. However, the clearance rate of the digestive system has to be taken account, explaining the delay in effect of reduced feed intake. It might also explain why effects are found to be related to weather conditions days back in time.

The results of Dikmen and Hanssen (2009) show that mean rectal temperature of lactating Holstein cows started to increase when dry air temperature was higher than $20^{\circ} \mathrm{C}$, wet bulb temperature higher than $19^{\circ} \mathrm{C}$ and THI higher than 65 , although with large variability around the mean. 
Table 3. Summary of results on variability of $\mathrm{kg}$ milk/d and dry air temperature $\left({ }^{\circ} \mathrm{C}\right)$, THI and rectal temperature $\left({ }^{\circ} \mathrm{C}\right) . \Delta$ means $\%$ increase or decrease

\begin{tabular}{|c|c|c|c|c|}
\hline Dry air temperature ${ }^{\circ} \mathrm{C}$ & THI & Rectal temperature $^{\circ} \mathbf{C}$ & Kg milk/d & \\
\hline $26.7^{\circ} \mathrm{C}+$ cooling & & & $41.4(0.13)$ & \\
\hline \multirow[t]{12}{*}{$27.0^{\circ} \mathrm{C}$} & & & $39.3(0.13)$ & Adin et al. (2009) \\
\hline & & & $\Delta=-5 \%$ & \\
\hline & & 38.5 & 40 & \\
\hline & & 39.0 & 35 & \\
\hline & & $\Delta=+1.3 \%$ & $\Delta=-12.5 \%$ & \\
\hline & & 39.5 & 30 & Tao and Dahl (2013) \\
\hline & & $\Delta=+2.6 \%$ & $\Delta=-25 \%$ & \\
\hline & 60 & 38.4 & 34 & \\
\hline & 70 & 39.0 & 32 & \\
\hline & $\Delta=+16.7 \%$ & $\Delta=+1.6 \%$ & $\Delta=-5.9 \%$ & \\
\hline & 80 & 39.6 & 30 & Zimbelman et al. (2009) \\
\hline & $\Delta=+33.3 \%$ & $\Delta=+3.1 \%$ & $\Delta=-11.8 \%$ & \\
\hline
\end{tabular}

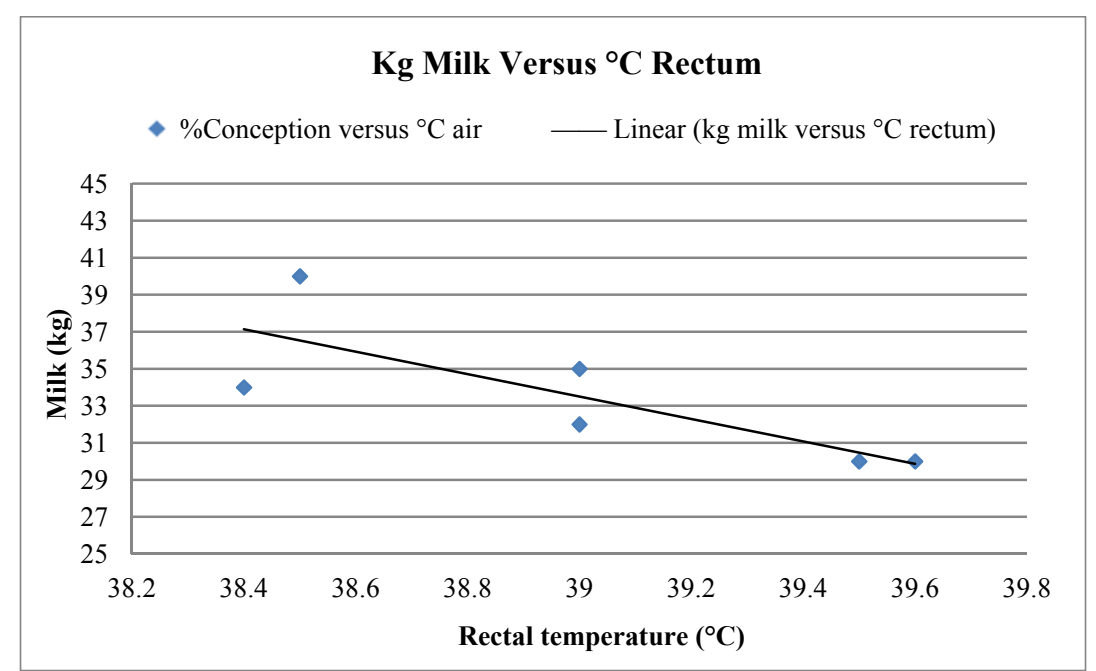

Figure 2. Daily milk production $(\mathrm{kg})$ versus rectal temperature $\left({ }^{\circ} \mathrm{C}\right)$, with $\mathrm{Kg}$ milk $=270-6.07{ }^{\circ} \mathrm{C}(\mathrm{r}=-0.7923$; $\mathrm{P}<0.05$ ), calculated with the results from Tao and Dahl (2013) and Zimbelman et al. (2007)

\section{Conclusions}

Production and reproduction characteristics of high producing dairy cows are sensitive to warm weather conditions being considered as mild heat stress. However, not only the level of dry air temperature and/or humidity as such has to be taken into account, but also their increase compared to the value associated with acclimation or adaptation as a reference. In most studies the value of THI is selected to defining alarming conditions. There seems to be a consensus to set the alarming level of THI between 60 and 65 for milk production at population level, but also for conception rate. The explanation for both has to be found in relation to the cow's thermoregulatory physiology and effects of a negative energy balance at animal level, taking into account individual variability. However, additional mechanisms specifically related to reproduction and/or lactation physiology have to be considered for a complete explanation (Walsh, Williams \& Evans, 2011).

Dry air temperature as such is most important, having significant effects from about $16{ }^{\circ} \mathrm{C}$ on, i.e. the higher the genetic potential for milk production, the lower the threshold for temperature at risk. Hence, the higher the risk of not being able to realize the genetic potential when interventions related to artificial cooling are not 
operational, e.g. providing shade to avoid radiation effects. This might also have implications on the cows' welfare. The counter effect on reproduction is enhanced when at the day of insemination dry air temperature is above a critical level in combination with effects of relative humidity, wind speed, rain intensity and radiation. Hence, it would be interesting to investigate whether or not the estimated error on the calculated breeding value is reduced when using actual information on weather conditions at the time of insemination or calving in stead of applying fixed correction factors for seasonal effects on genetic parameters with respect to production and reproduction.

The effects have to be considered as important, especially in a system with year round calving, since production might be about six months of the year below peak production (see weather conditions presented in Table 1), due to time necessary to recover from bottom to peak production related to warm weather conditions. Possible interventions suggested in the literature are aiming to reduce heat production: on pasture during the night in case of being connected with the farm buildings, feed with a low heat increment, forced ventilation and air conditioning when cows are indoors (Saucedo-Quintero, Robinson, \& Fadel, 2006). Hence, selection for heat tolerance should be based on production results collected in summer, although the significant effect on production results during summer seems also related with other factors to be investigated.

The financial impact for the farmer might be substantial. Inchaisri, Jorritsma, Vos, van der Weijden, and Hogeveen (2010) calculated for dairy farms in The Netherlands an economic impact on reproductive performance varying from $-34 \mathrm{EUR} / \mathrm{cow}$ when management is optimal, to $-231 \mathrm{EUR} / \mathrm{cow}$ when management is suboptimal. The genetic progress will be more counteracted by heat stress for reproductive performance, since $\mathrm{h}^{2}$ values are much lower than for production characteristics, especially in suboptimal managed farms (Roibas \& Alvarez, 2010; Weller \& Ezra, 2004).

It can be concluded that high producing dairy cows apply acclimatization mechanisms when dry air temperature increases in mild weather conditions. However, it might be expected that providing protection (trees, shelter) on pasture will not improve (re)production, but only animal welfare, i.e. thermal comfort. The level of dry air temperature seems to be the most important factor, which has mostly the same value in- or outside, due to ventilation events. Hence, there will not be a direct return of investment moneywise for providing shelter, but indirectly by improving animal welfare and meeting societal concerns. Animal welfare will be improved, because cows have the possibility to choose. It has been proven that cow's energy expenses are reduced when coping with heat stress is easy and successfully to maintain homoeothermy. Legislation, which should be guidelines based on scientific evidence, is only necessary in case farmers are not convinced that animal welfare is an important aspect of sustainable production.

\section{Acknowledgements}

This study was funded by the Federal Public Service of Health, Food Chain Safety and Environment (Belgium) (contractRT10/13 PASSTRESS). The Royal Meteorological Institute of Belgium and The Netherlands provided the data from weather stations.

\section{References}

Adin, G., Gelman, A., Solomon, R., Flamenbaum, I., Nikbachat, M., Yosef, E., ... Miron, J. (2009). Effects of cooling dry cows under heat load conditions on mammary gland enzymatic activity, intake of food and water, and performance during the dry period and after parturition. Livestock Science, 124, 189-195. http://dx.doi.org/10.1016/j.livsci.2009.01.014

Ainsworth, J. A. W., Moe, S. R., \& Skarpe, C. (2012). Pasture shade and farm management effects on cow productivity in the tropics. Agriculture, Ecosystems and Environment, 155, 105-110. http://dx.doi.org/10.1016/j.agee.2012.04.005

Amundson, J. L., Mader, T. L., Rasby, R. J., \& Hu, Q. S. (2006). Environmental effects on pregnancy rate in beef cattle. Journal of Animal Science, 84, 3415-3420. http://dx.doi.org/10.2527/jas.2005-611

Avendaño-Reyes, L., Alvarez-Valenzuela, F. D., Correa-Calderón, A., Saucedo-Quintero, J. S., Robinson, P. H., \& Fadel, J. G. (2006). Effect of cooling Holstein cows during the dry period on postpartum performance under heat stress conditions. Livestock Science, 105, 198-206. http://dx.doi.org/10.1016/j.livsci.2006.06.009

Barash, H., Silanikove, N., Shamay, A., \& Ezra, E. (2001). Interrelationships among ambient temperature, day length, and milk yield in dairy cows under a mediterranean climate. Journal of Dairy Science, 84, 2314-2320. http://dx.doi.org/10.3168/jds.S0022-0302(01)74679-6

Berman, A. (2011). Are adaptations present to support dairy cattle productivity in warm climates? Journal of 
Dairy Science, 94, 2147-2158. http://dx.doi.org/10.3168/jds.2010-3962

Berman, A., \& Horovitz, T. (2012). Radiant heat loss, an unexploited path for heat stress reduction in shaded cattle. Journal of Dairy Science, 95, 3021-3031. http://dx.doi.org/10.3168/jds.2011-4844

Bertocchi, L., Vitali, A., Lacetera, N., Nardone, A., Varisco, G., \& Bernabucci, U. (2014). Seasonal variations in the composition of Holstein cow's milk and temperature-humidity index relationship. Animal, 8, 667-674. http://dx.doi.org/10.1017/S1751731114000032

Bligh, J. (1966). The thermosensitivity of the hypothalamus and thermoregulation in animals. Biological Reviews, 41, 317-367. http://dx.doi.org/10.1111/j.1469-185X.1966.tb01496.x

Bohmanova, J., Misztal, I., \& Cole, J. B. (2007). Temperature-humidity indices as indicators of milk production losses due to heat stress. Journal of Dairy Science, 90, 1947-1956. http://dx.doi.org/10.3168/jds.2006-513

Brown-Brandl, T. M., Jones, D. D., \& Woldt, W. E. (2005). Evaluating modelling techniques for cattle heat stress prediction. Biosystems Engineering, 91, 513-524. http://dx.doi.org/10.1016/j.biosystemseng.2005.04.003

Brown-Brandl, T. M., Eigenberg, R. A., Nienaber, J. A., \& Hahn, G. L. (2005). Dynamic response indicators of heat stress in shaded and non-shaded feedlot cattle, Part 1: Analyses of indicators. Biosystems Engineering, 90, 451-462. http://dx.doi.org/10.1016/j.biosystemseng.2004.12.006

Brügemann, K., Gernand, E., von Borstel, U. U., \& König, S. (2011). Genetic analyses of protein yield in dairy cows applying random regression models with time-dependent and temperature $\mathrm{x}$ humidity-dependent covariates. Journal of Dairy Science, 94, 4129-4139. http://dx.doi.org/10.3168/jds.2010-4063

Butler, G., Stergiadis, S., Seal, C., Eyre, M., \& Leifert, C. (2011). Fat composition of organic and conventional retail milk in northeast England. Journal of Dairy Science, 94, 24-36. http://dx.doi.org/10.3168/jds.2010-3331

Casasús, I., Sanz, A., Villalba, D., Ferrer, R., \& Revilla, R. (2002). Factors affecting animal performance during the grazing season in a mountain cattle production system. Journal of Animal Science, 80, 1638-1651.

Cavestany, D., EL-Wishy, A. B., \& Foote, R. H. (1985). Effect of season and high environmental temperature on fertility of Holstein cattle. Journal of Dairy Science, 68, 1471-1478. http://dx.doi.org/10.3168/jds.S0022-0302(85)80985-1

Charles, D. R. (1994). Comparative climatic requirements. In C. M. Wathes, \& D. R. Charles (Eds.), Livestock housing (pp. 3-24). Walingford, UK: CAB International.

Christopherson, R. J. (1985). Management and housing of animals in cold environments. In M. K. Yousef (Ed.), Stress physiology in livestock (pp. 97-108). Boca Raton, USA: CRC Press.

Collier, R. J., Zimbelman, R. B., Rhoads, R. P., Rhoads, M. L., \& Baumgard, L. H. (2006). A re-evaluation of the impact of temperature humidity index (THI) and black globe humidity index (BGHI) on milk production in high producing dairy cows. Western Dairy Management Conference (pp. 113-125). March 9-11 Reno, NV.

Curtis, S. E. (1983). Environmental management in animal agriculture. The Iowa State University Press, Ames, USA.

De Rensis, F., \& Scaramuzzi, R. J. (2003). Heat stress and seasonal effects on reproduction in the dairy cow-A review. Theriogenology, 60, 1139-1151. http://dx.doi.org/10.1016/S0093-691X(03)00126-2

Dikmen, S., \& Hansen, P. J. (2009). Is the temperature-humidity index the best indicator of heat stress in lactating dairy cows in a subtropical environment? Journal of Dairy Science, 92, 109-116. http://dx.doi.org/10.3168/jds.2008-1370

Eigenberg, R. A., Brown-Brandl, T. M., Nienaber, J. A., \& Hahn, G. L. (2005). Dynamic response indicators of heat stress in shaded and non-shaded feedlot cattle, Part 2: Predictive relationships. Biosystems Engineering, 91, 111-118. http://dx.doi.org/10.1016/j.biosystemseng.2005.02.001

Falk, A. C., Weary, D. M., Winckler, C., \& von Keyserlingk, M. A. G. (2012). Preference for pasture versus freestall housing by dairy cattle when stall availability indoors is reduced. Journal of Dairy Science, 95, 6409-6415. http://dx.doi.org/10.3168/jds.2011-5208

Fraser, A. F. (1985). Ethology of Farm Animals. Amsterdam, The Netherlands: Elsevier.

Fisher, A. D., Roberts, N., Bluette, J. S., Verkerk, G. A., \& Matthews, L. R. (2008). Effects of shade provision on the behaviour, body temperature and milk production of grazing dairy cows during a New Zealand summer. 
New Zealand Journal of Agricultural Research, 51, 99-105. http://dx.doi.org/10.1080/00288230809510439

Gwazdauskas, F. C. (1985). Effects of climate on reproduction in cattle. Journal of Dairy Science, 68, 1568-1578. http://dx.doi.org/10.3168/jds.S0022-0302(85)80995-4

Hammami, H., Bormann, L., M'hamdi, N., Montaldo, H. H., \& Gengler, N. (2013). Evaluation of heat stress effects on production traits and somatic cell score of Holsteins in a temperate environment. Journal of Dairy Science, 96, 1844-1855. http://dx.doi.org/10.3168/jds.2012-5947

Hansen, P. J., \& Aréchiga, C. F. (1997). Strategies for managing reproduction in the heat-stressed dairy cow. Journal of Animal Science, 77, 36-50.

Inchaisri, C., Jorritsma, R., Vos, P. L. A. M., van der Weijden, G. C., \& Hogeveen, H. (2010). Economic consequences of reproductive performance in dairy cattle. Theriogenology, 74, 835-846. http://dx.doi.org/10.1016/j.theriogenology.2010.04.008

Ingraham, R. H., Gillette, D. D., \& Wagner, W. D. (1971). Relationship of temperature and humidity to conception rate of Holstein cows in Subtropical climate. Journal of Dairy Science, 57, $476-481$. http://dx.doi.org/10.3168/jds.S0022-0302(74)84917-9

Johnson, H. D. (1987). Bioclimatology and the Adaptation of Livestock. Amsterdam, The Netherlands: Elsevier.

Johnson, J. S., Scharf, B., Weaber, R. L., Eichen, P. A., \& Spiers, D. E. (2012). Patterns of heat response and adaptation on summer pasture: A comparison of heat-sensitive (Angus) and -tolerant (Romosinuano) cattle. Journal of Thermal Biology, 37, 344-350. http://dx.doi.org/10.1016/j.jtherbio.2011.10.014

Jordan, E. R. (2003). Effects of heat stress on reproduction. Journal of Dairy Science, 86, E104-E114. http://dx.doi.org/10.3168/jds.S0022-0302(03)74043-0

Kadzere, C. T., Murphy, M. R., Silanikove, N., \& Maltz, E. (2002). Heat stress in lactating dairy cows: A review. Livestock Production Science, 77, 59-91. http://dx.doi.org/10.1016/S0301-6226(01)00330-X

Kendall, P. E., Nielsen, P. P., Webster, J. R., Verkerk, G. A., Littlejohn, R. P., \& Matthews, L. R. (2006). The effects of providing shade to lactating dairy cows in a temperate climate. Livestock Science, 103, 148-157. http://dx.doi.org/10.1016/j.livsci.2006.02.004

Legrand, L., von Keyserlingk, M. A. G., \& Weary, D. M. (2008). Preference and usage of pasture versus free-stall housing by lactating dairy cattle. Journal of Dairy Science, 92, 3651-3658. http://dx.doi.org/10.3168/jds.2008-1733

Mader, T. L., Johnson, L. J., \& Gaughan, J. B. (2010). A comprehensive index for assessing environmental stress in animals. Journal of Animal Science, 88, 2153-2165. http://dx.doi.org/10.2527/jas.2009-2586

Moher, D., Liberati, A., Tetzlaff, J., \& Altman, D. G. (2009). The PRISMA Group - Preferred Reporting Items for Systematic Reviews and Meta-Analyses: The PRISMA Statement. PLoS Med., 6(6), e1000097. http://dx.doi.org/0.1371/journal.pmed1000097

Morton, J. M., Tranter, W. P., Mayer, D. G., \& Jonsson, N. N. (2007). Effects of environmental heat on conception rates in lactating dairy cows: Critical periods of exposure. Journal of Dairy Science, 90, 2271-2278. http://dx.doi.org/10.3168/jds.2006-574

Nabenishi, H., Ohta, H., Nishimoto, T., Morita, T., Ashizawa, K., \& Tsuzuki, Y. (2011). Effect of temperature-humidity index on body temperature and conception rate of lactating dairy cows in Southwestern Japan. Journal of Reproduction and Development, 57, 450-456.

Nardone, B., Ronchi, N., Lacetera, O., \& Bernabucci, U. (2006). Climatic effects on productive traits in livestock. Veterinary Research Communications, 30 (Supplement 1), 5-81. http://dx.doi.org/10.1007/s11259-006-0016-x

Nienaber, J. A., \& Hahn, G. L. (2007). Livestock production system management responses to thermal challenges. International Journal of Biometeorology, 52, 149-157. http://dx.doi.org/10.1007/s00484-007-0103-x

Paula-Lopes, F. F., Lima, R. S., Satrapa, R. A., \& Barros, C. M. (2013). Influence of cattle genotype (Bos indicus vs. Bos taurus) on oocyte and preimplantation embryo resistance to increased temperature. Journal of Animal Science, 91, 1143-1153. http://dx.doi.org/10.2527/jas.2012-5802

Peel, M. C., Finlayson, B. L., \& McMahon, T. A. (2007). Updated world map of the Köppen-Geiger climate classification. Hydrol. Earth Syst. Sci., 11, 1633-1644. http://dx.doi.org/10.5194/hess-11-1633-2007 
Ravagnolo, O., \& Misztal, I. (2002). Effect of heat stress on nonreturn rate in Holsteins: Basic and applied aspects. Animal Reproduction Science, 60-61, 535-547.

Roelofs, J., López-Gatiusc, F., Hunterd, R. H. F., van Eerdenburge, F. J. C. M., \& Hanzen, Ch. (2010). When is a cow in estrus? Clinical and practical aspects. Theriogenology, 74, 327-344. http://dx.doi.org/10.1016/j.theriogenology.2010.02.016

Roibas, D., \& Alvarez, A. (2010). Impact of genetic progress on the profits of dairy farmers. Journal of Dairy Science, 93, 4366-4373. http://dx.doi.org/10.3168/jds.2010-3135

Saucedo-Quintero, J. S., Robinson, P. H., \& Fadel, J. G. (2006). Effect of cooling Holstein cows during the dry period on postpartum performance under heat stress conditions. Livestock Science, 105, 198-206. http://dx.doi.org/10.1016/j.livsci.2006.06.009

Schütz, K. E., Cox, N. R., \& Matthews, L. R. (2008). How important is shade to dairy cattle? Choice between shade or lying following different levels of lying deprivation. Applied Animal Behaviour Science, 114, 307-318. http://dx.doi.org/10.1016/j.applanim.2008.04.001

Schütz, K. E., Rogers, A. R., Poulouin, Y. A., Cox, N. R., \& Tucker, C. B. (2010). The amount of shade influences the behavior and physiology of dairy cattle. Journal of Dairy Science, 93, 125-133. http://dx.doi.org/10.3168/jds.2009-2416

Shearer, J. K., \& Beede, D. K. (1990). Thermoregulation and physiological responses of dairy cattle in hot weather. Agricultural Practice, 11, 5-11.

Silanikove, N. (2000). Effects of heat stress on the welfare of extensively managed domestic ruminants. Livestock Production Science, 67, 1-18.

Smith, D. L., Smith, T., Rude, B. J., \& Ward, S. H. (2013). Comparison of the effects of heat stress on milk and component yields and somatic cell score in Holstein and Jersey cows. Journal of Dairy Science, 96, 3028-3033. http://dx.doi.org/10.3168/jds.2012-5737

Smith, T. R., Chapa, A., Willard, S., Herndon, Jr., C., Williams, R. J., Crouch, J., ... Pogue, D. (2006). Evaporative tunnel cooling of dairy cows in the Southeast. II: Impact on lactation performance. Journal of Dairy Science, 89, 3915-3923. http://dx.doi.org/10.3168/jds.S0022-0302(06)72433-X

Stigler, S. (1986). The History of Statistics (p. 203). Cambridge: Harvard University Press.

Tao, S., \& Dahl, G. E. (2013). Heat stress effects during late gestation on dry cows and their calves. Journal of Dairy Science, 96, 4079-4093. http://dx.doi.org/10.3168/jds.2012-6278

Thom, E. C. (1959). The discomfort index. Weatherwise, 12, 57-59. http://dx.doi.org/10.1080/00431672.1959.9926960

Thompson, V. A., Fadel, J. G., \& Sainz, R. D. (2011). Meta-analysis to predict sweating and respiration rates for Bos indicus, Bos taurus, and their crossbreds. Journal of Animal Science, 89, 3973-3982. http://dx.doi.org/10.2527/jas.2011-3913

Tucker, C. B., Rogers, A. R., Verkerk, G. A., Kendall, P. E., Webster, J. R., \& Matthews, L. R. (2007). Effects of shelter and body condition on the behavior and physiology of dairy cattle in winter. Applied Animal Behaviour Science, 105, 1-13. http://dx.doi.org/10.1016/j.applanim.2006.06.009

Tucker, C. B., Rogers, A. R., \& Schütz, K. E. (2008). Effect of solar radiation on dairy cattle behaviour, use of shade and body temperature in a pasture-based system. Applied Animal Behaviour Science, 109, $141-154$. http:/dx.doi.org/10.1016/j.applanim.2007.03.015

Umphrey, J. E., Moss, B. R., Wilcox, C. J., \& Van Horn, H. H. (2001). Interrelationships in lactating Holsteins of rectal and skin temperatures, milk yield and composition, dry matter intake, body weight, and feed efficiency in Summer in Alabama. Journal of Dairy Science, 84, 2680-2685. http://dx.doi.org/10.3168/jds.S0022-0302(01)74722-4

Vandenheede, M., Nicks, B., Shehi, R., Canart, B., Dufrasne, L., Biston, L., \& Lecomte, P. (1992). Modalités d'utilisation d'un abri par des taurillons au pâturage. Annales Médicine Vétérinaire, 136, 321-325.

Walsh, S. W., Williams, E. J., \& Evans, A. C. O. (2011). A review of the causes of poor fertility in high milk producing dairy cows. Animal Reproduction Science, 123, 127-138. http://dx.doi.org/10.1016/j.anireprosci.2010.12.001

Weller, J. I., \& Ezra, E. (2004). Genetic analysis of the Israeli Holstein dairy cattle population for production and 
nonproduction traits with a multitrait animal model. Journal of Dairy Science, 87, 1519-1527. http://dx.doi.org/10.3168/jds.S0022-0302(04)73303-2

Wenz, J. R., Moore, D. A., \& Kasimanickam, R. (2011). Factors associated with the rectal temperature of Holstein dairy cows during the first 10 days in milk. Journal of Dairy Science, 94, 1864-1872. http://dx.doi.org/10.3168/jds.2010-3924

West, J. W. (2003). Effects of heat stress on production in dairy cattle. Journal of Dairy Science, 86, 2131-2144. http://dx.doi.org/10.3168/jds.S0022-0302(03)73803-X

Wolfenson, D., Roth, Z., \& Meidan, R. (2000). Impaired reproduction in heat-stressed cattle: Fixed-model analyses. Journal of Dairy Science, 85, 3101-3106.

Yousef, M. K. (1985). Stress Physiology in Livestock. Boca Raton, USA: CRC Press.

Zimbelman, R. B., Rhoads, R. P., Rhoads, M. L., Duff, G. C., Baumgard, L. H., \& Collier, R. J. (2009). A re-evaluation of the impact of temperature humidity index (THI) and black globe humidity index (BGHI) on milk production in high producing dairy cows. CSREES NRI Grant \# 2006-01724 (p. 12).

\section{Copyrights}

Copyright for this article is retained by the author(s), with first publication rights granted to the journal.

This is an open-access article distributed under the terms and conditions of the Creative Commons Attribution license (http://creativecommons.org/licenses/by/3.0/). 